\title{
Solving the Problems of Rural Development as Environmentally Desirable Segment of Sustainable Development
}

\author{
Vladan Joldžić $^{1 *}$ | Ana Batrićevićc ${ }^{1}$ Vera Stanković ${ }^{1}$ | Nikola Paunović \\ ${ }^{1}$ Institute of Criminological and Sociological Research, Belgrade, Serbia
}

\begin{abstract}
The paper highlights key problems of rural development in the context of economic and environmental crisis, with focus on rural areas in Serbia. It emphasizes the link between sustainable rural development and environmental protection, particularly in the fields of organic agriculture, small organic farming and agro-eco tourism. It analyses legislative and strategic documents regulating this issue on universal, European and national level, making suggestions to improve their application. Obstacles for sustainable rural development include: uncultivated agricultural lands, soil pollution, insufficient irrigation or draining, agricultural lands fragmentation, poor infrastructure, inadequate tax policy, uncompleted restitutions, long probate proceedings and financially uncertain position of land-owners. Some of them have environmental impacts and can be resolved by suitable policy and legislation, strategic planning, environmental education and financial stimuli for green agriculture. The paper suggests legislators and policy makers in the areas of: sustainable development, taxes, agriculture, green economy and environment protection to analyse more profoundly key problems of rural development and their linkage to nature conservation. When it comes to practice, it suggests which legal documents should be applied in order to achieve successful, sustainable and environmentally acceptable development of rural areas. The paper contributes to a better understanding of the relationship between sustainable rural development and environment protection, emphasizing the possibility to preserve nature and increase incomes of rural communities through green agriculture, small farm production and eco-tourism. It also states that current legislative framework provides preconditions for resolving the issues that might appear within, suggesting key steps for its future implementation.
\end{abstract}

Key words: sustainable development, rural development, agriculture, eco-tourism, environment protection, ecology, green economy

JEL Classification: Q01, Q57

\section{INTRODUCTION}

The most widely accepted definition of sustainable development is the one from the Report of the World Commission on Environment and Development: Our Common Future, also known as the Brundtland Report. It describes sustainable development as "development that meets the needs of the present without compromising the ability of future generations to meet their own needs" (World Commission on Environment and Development, 1987). National Sustainable Development Strategy of the Republic of Serbia defines sustainable development as targetsoriented, long-term (continuous), comprehensive and synergetic process with impacts on all

\footnotetext{
*E-mail: vladanj@eunet.rs
} 
aspects of life (economic, social, environmental and institutional) at all levels (National Sustainable Development Strategy, Official Gazette of the Republic of Serbia, No. 57/2008).

In its Paragraph 54, the United Nations' Resolution "Transforming our world: the 2030 Agenda for Sustainable Development", adopted in 2015, proclaims 17 "Global Goals" of sustainable development with 169 targets between them. They include the following: 1) end poverty in all its forms everywhere; 2 ) end hunger, achieve food security and improved nutrition and promote sustainable agriculture; 3 ) ensure healthy lives and promote well-being for all at all ages; 4) ensure inclusive and equitable quality education and promote lifelong learning opportunities for all; 5) achieve gender equality and empower all women and girls; 6) ensure availability and sustainable management of water and sanitation for all; 7) ensure access to affordable, reliable, sustainable and modern energy for all; 8) promote sustained, inclusive and sustainable economic growth, full and productive employment and decent work for all; 9) build resilient infrastructure, promote inclusive and sustainable industrialization and foster innovation; 10) reduce inequality within and among countries; 11) make cities and human settlements inclusive, safe, resilient and sustainable; 12) ensure sustainable consumption and production patterns; 13) take urgent action to combat climate change and its impacts; 14) conserve and sustainably use the oceans, seas and marine resources for sustainable development; 15) protect, restore and promote sustainable use of terrestrial ecosystems, sustainably manage forests, combat desertification, and halt and reverse land degradation and halt biodiversity loss; 16) promote peaceful and inclusive societies for sustainable development, provide access to justice for all and build effective, accountable and inclusive institutions at all levels and 17) strengthen the means of implementation and revitalize the global partnership for sustainable development.

As stated in Paragraph 55 of the Agenda, "the Sustainable Development Goals and targets are integrated and indivisible, global in nature and universally applicable, taking into account different national realities, capacities and levels of development and respecting national policies and priorities". However, each state is free to decide how the global targets should be implemented into their national planning processes, policies and strategies. It is also emphasized that the link between sustainable development and other relevant ongoing processes in the economic, social and environmental areas should be recognised. By insisting on the correlation between economic, social and environmental fields in the process of sustainable development, Paragraph 55 of the Agenda implies that sustainable development comprises three interrelated components or aspects that should not be perceived as independent one from another.

National Sustainable Development Strategy of the Republic of Serbia highlights that sustainable development involves the need to harmonize the different aspects of development and the contradictory ideas included in each individual sectoral program. Accordingly, the Strategy's key objective is to establish a balance between the three key factors, or three pillars, of sustainable development: 1) sustainable economic growth, economic and technological progress, 2) sustainable social development, based on social balance, and 3) environmental protection accompanied by reasonable use of natural resources. The Strategy attempts to join these three pillars within an adequate institutional framework.

\section{SUSTAINABLE RURAL DEVELOPMENT}

The term "rural" appears to be rather vague. Although there is no exact definition of that term, rural areas can be clearly recognised. They form the space where human settlements and infrastructure occupy only small parts of landscape, whereas fields, pastures, woods, forests, waters, mountains and deserts tend to be predominant. In rural areas, people usually live in farmsteads or settlements of not more than 10.000 persons. However, the differences between urban and rural settlements vary from one country to another (Ashley \& Maxwell, 2001). 
Rural development represents "a multi-level process rooted in historical traditions" (Van der Ploeg et al., 2000: 391-392). Today, it is related to a general restructuring of the economy at the global level and can be in part perceived as a response of the farm enterprises to new, more flexible trends in firms' organisation. Furthermore, modern rural development implies a new developmental model for the agricultural sector and a cohesion at farm level but also between different farms or farms and other rural activities as well as between local and regional ecosystems, specific farm-styles, goods, services etc. (Van der Ploeg et al., 2000).

Rural development can be observed either as a development policy managed by the state or as a broader concept of rural society change with or without state interventions. This implies that rural development refers to interventions of much more extensive character than agricultural development as well as to the process of rural society change that is not always directly influenced by the state (Bogdanov, 2007).

Rural development should be perceived as a multi-actor process, involving a complex institutional setting. It is also multi-faceted process since it comprises a wide range of different practices, some of which are interconnected. These practices include: landscape management, natural values conservation, agro-tourism, organic farming and the production of high-quality and region-specific products (Van der Ploeg et al., 2000: 394). Rural development also comprises nature conservation and landscape management and the development of short supply chains. All these activities are rather new and their number and variety actually seems to be much larger (Knickel \& Renting, 2000).

Environmental sustainability is considered an important component of rural development is also given a significant amount of attention, especially in the European Union. (Ristić, 2013). The link between rural development and environmental protection was recognised for the first time in the 1980s, when agro-ecology emerged as an attempt to establish a scientific basis for alternatives to industrialized agriculture. The agro-ecological framework is based upon different intellectual traditions and disciplines, such as: peasant studies, ecology and environmentalism and development theory. It implies an alternative definition of sustainability from which an ecologically oriented discourse is shaped. Its central concept is co-evolution of society and natural factors, i.e. humans and nature. (Marsden et al, 2001).

There are many aspects of rural development that are related to environmental protection: rural or agro tourism, agriculture and organic farming and food production are some of the most important ones.

In accordance with the modern concept of rural development, agriculture is supposed to be multifunctional, which means that it includes some other activities that are not directed only towards the increase of production but comprise other benefits of rural environment. Multifunctional agriculture has several aspects and one of them is environmental protection, i.e. conservation of biodiversity, preservation of natural landscapes and protection from floods, and erosion. Namely, it has been converted from agriculture of production to agriculture of protection (Pejanović \& Vujović, 2008). Being socially, economically and ecologically acceptable, organic agriculture can significantly contribute to sustainable development of rural areas (Ristić, 2013).

Due to declining economic activity, agricultural reforms, restructuring of the agricultural sector, deteriorating rural industrialisation and out-migration of educated young people from rural to urban areas, many rural communities have adopted tourism as an alternative development strategy. Rural tourism is seen as a means for the economic and social regeneration of rural areas, particularly In Eastern Europe, and less developed countries of subSaharan Africa, affected by rural poverty (Briedenhann \& Wickens, 2004).

Rural, as a specific type of eco-tourism is already developing in some parts of Serbia and should be strongly supported, in particular as a means to promote and enhance the conservation of environment. Eco-tourism is considered environmentally responsible, it includes a low visitor 
impact, and contributes to socioeconomic participation of local populations (Scheyvens, 1999). This type of tourism is also addressed to as agro-tourism and is also important for rural development. It is a type of tourism focused on healthy nutrition of tourists and spending time in healthy environment that is accomplished through the development of agriculture with respect to different aspects of sustainability (Pejanović \& Vujović, 2008).

Tourism development has the potential to generate new jobs, improve community infrastructure and assist in revitalising the weakening economies of rural areas. That is the reason why governments often tend to see it as a solution to the problems of rural areas. But, it has to be developed wisely in order to avoid lack of incomes, the unfairness of profit distribution and the social costs to resident communities (Briedenhann \& Wickens, 2004). Therefore, it is important that local communities have some control over it and share the benefits it provides, which can only be provided if conservation and development at the local level are promoted (Scheyvens, 1999).

\section{PROBLEMS AFFECTING RURAL AREAS}

In the past couple of decades, the state of rural development has been rather troubled, primarily due to rural poverty, decline in funding to the agricultural sector and inappropriate policy created by international funding agencies and developing country governments (Ashley \& Maxwell, 2001). In spite of the fact that the importance of agriculture varies significantly from one European country to another, its general significance seemed to be decreasing in the past decade (Van der Ploeg et al., 2000). In the eyes of public and policy-makers, the agricultural sector has been considered detached, over-subsidized and unattractive because of crisis in food production, growing health risks, environmental loss, overproduction of low-quality products and the decline in number of producers and farm workers (Marsden et al, 2001).

Poverty, marginalization, depopulation and low quality of life in rural areas causing village decay are now identified as a global problem (Vasilevska, 2010). In developed countries, rural poverty is observed in the context of lower incomes per capita in rural areas in comparison to average national incomes and incomes in urban areas. Poverty of some rural areas leads to their social exclusion, causes lower education and diminishes their developmental possibilities, similar to ghettos in urban areas. Poverty in both - rural as well as urban areas also results in the degradation of natural environment and has negative implications in social and economic sphere (Bogdanov, 2007).

The link between poverty and environment is often mentioned in the context of sustainable development. This refers to rural poverty as well, since rural development is particularly dependent on natural resources. Researches show that high level of rural poverty and unemployment is most commonly closely related to the fact that rural areas predominantly depend on agriculture. The experiences of developed countries in resolving the problems of economic and demographic devastation of rural areas have confirmed that the policy of sustainable rural development should not support only agriculture but non-agricultural economic activities (Ristić, 2013). The aforementioned is particularly important for environmentally fragile and poor rural areas, where incomes from agriculture are faced with the high risk and should be replaced with non-agricultural activities such as gathering (local flora and fauna, farming and livestock husbandry (Reardon \& Vosti, 1995).

\section{PROBLEMS OF RURAL DEVELOPMENT IN SERBIA}

Rural areas comprise around $85 \%$ of Serbia's territory and are the home of one half of its population. There are altogether 5.965 rural settlements in Serbia, whereas 6.158 are considered urban. Demographic trends in rural areas are increasingly negative, primarily due to migration and negative birth rate. Due to that, rural population comprises $40.6 \%$ of Serbia's 
population (Strategy of agriculture and rural development of the Republic of Serbia for the period between 2014 and 2024, Official Gazette of the Republic of Serbia, No. 85/2014).

Natural resources (including agricultural lands, forests, waters, flora, fauna and cultural heritage) represent important components of rural areas in Serbia. Despite their natural potentials, rural areas in Serbia are facing an array of persistent problems such as: negative demographic trends, undeveloped infrastructure, fragmented agricultural households that are not market-oriented, inadequate structure of production, low productivity rate, minimal household incomes, large share of agriculture in rural economy, low rate of diversification of rural economy, high unemployment rate, insufficient trading capacities, poor organisation, inability to compete with foreign producers, lack of state support etc. (Pejanović, 2009; Ristić, 2013). The crisis of Serbian agriculture has been lasting for a long time and long-term problems that emerged as the consequences of lack of systematic and continuous economic policy measures caused a permanently inconvenient situation in agriculture (Pejanović, 2009).

As stated in National Sustainable Development Strategy, intensive urbanization and industrialization in Serbia have caused intensive migrations from rural to urban areas, massive loss of large fertile agricultural lands and decelerated socio-economic and cultural development of rural areas. The lack of systematic state support to integral rural development also contributed to the neglect and abandonment of households, agricultural lands and other natural resources in rural areas. Nowadays, natural, infrastructural and other conditions relevant to agricultural production differ from one rural area to another. These differences affect social development, demographic characteristics, cultural features, attitudes towards tradition, views on modernization and environmental awareness of individual rural areas (National Sustainable Development Strategy, Official Gazette of the Republic of Serbia, No. 57/2008).

Numerous problems related to rural development also affect components of the environment such as: soil, water and forests. The main threats for soil quality include: soil acidification, minimisation of organic particles' level in the soil, soil pollution and erosion. For example, more than one quarter of agricultural lands in Serbia are acidified, as the result of uncontrolled use of chemical substances and some areas in the province of Vojvodina (around 14\%) are salted. Irrigation of soil is also not conducted in an appropriate manner. A small share of agricultural land is irrigated legally, some are irrigated only partially and the number of parcels irrigated without necessary permission is much larger. One of the most delicate issues regarding future development of agricultural sector in Serbia is a very inconvenient age and educational structure of population involved with this type of production. This problem might affect social structure of rural areas as well as the capacities of human resources to adopt and implement new technologies, changes in production structure etc. (National Sustainable Development Strategy, Official Gazette of the Republic of Serbia, No. 57/2008). Rural households are not equipped with modern technologies, their production is not enough specialised and the motivation of employees is not very high due to low incomes (Pejanović, 2009).

In spite of efforts of relevant institutions directed towards the conservation of biodiversity including the ratification of international treaties, adoption of national legislative framework and establishing of numerous protected areas, Serbia is still facing obstacles when it comes to the implementation of policies and strategies in this field. Insufficient financial resources, missing of appropriate institutional framework, lack of monitoring and information systems are some of the reasons causing such situation. Closely related to the issues regarding biodiversity are the problems in the area of forestry. Around 29\% of forests are devastated, natural forests are rather old and their natural renewing is missing, some of the forests are dry and there are not enough forest roads. All these problems lead to insufficient use of forests' potentials. Serbia has made significant improvements when it comes to legislative framework dedicated to animal welfare. However, the condition in this field, especially when farm animals and animals in traffic are concerned, is still not in accordance with international standards. This affects livestock 
production and has a negative impact on the trust of foreign consumers (National Sustainable Development Strategy, Official Gazette of the Republic of Serbia, No. 57/2008).

\section{LEGISLATIVE AND STRATEGIC MEASURES FOR RESOLVING THE PROBLEMS OF RURAL DEVELOPMENT}

\section{United Nations}

The UN Sustainable Development Agenda incorporates rural development in the goals of sustainable development, with special focus on developing and least developed countries. According to its Paragraph 24, the states have made commitment to devote their resources to developing rural areas and sustainable agriculture and fisheries, supporting smallholder farmers, especially women farmers, herders and fishers in developing and least developed countries. In its second goal (end hunger, achieve food security and improved nutrition and promote sustainable agriculture), the Agenda mentions rural development in the context of investment in rural infrastructure, agricultural research and extension services, technology development and plant and livestock gene banks in order to enhance agricultural productive capacity in developing countries, in particular least developed countries. Within its eleventh goal, dedicated to making human settlements inclusive, safe, resilient and sustainable, the Agenda promotes supporting of positive economic, social and environmental links between urban, peri-urban and rural areas by strengthening national and regional development planning.

The Economic and Social Council of the United Nations plays an important role in the promotion of sustainable rural development on a global level. For example, Ministerial declaration on Promoting an integrated approach to rural development in developing countries for poverty eradication and sustainable development(http://www.un.org/esa/coordination/Alliance/documents/website/ministerial\% 20declaration.pdf) adopted in 2003 among other issues, states that the eradication of rural poverty and hunger is critical to the achievement of the internationally agreed development goals, including the Millennium Development Goals. It suggests that rural development should be an integral part of national and international development policies, including bilateral donor response strategies and the activities and programmes of the United Nations system.

The Declaration emphasizes that rural development should be pursued through an integrated approach, encompassing the economic, social and environmental dimensions. It should also take into account the gender perspective and consisting of mutually reinforcing policies and plans. Such approach to rural development is supposed to be balanced, targeted, situation specific and locally owned. It must include local synergies and initiatives and be responsive to the needs of rural populations. Although the declaration considers rural development the responsibility of each country it claims that enabling international economic environment is significant to support effective national development efforts, including rural development efforts.

Empowerment of population living in poor rural areas is strongly supported by the Declaration. It is particularly pointed out that poor people living in rural areas should play a full and effective role in their development by participating in the decision-making processes, relevant to: resource allocation; promoting mechanisms. They are encouraged to influence the market and public policies as well as to participate fully in the design, development and implementation of rural development strategies and programmes.

Environmental protection is also mentioned in the Declaration. The declaration reaffirms that sustainable agriculture and rural development are vital to the implementation of an integrated approach to food security and safety in an environmentally sustainable way. It states that rural populations play an important role in sustainably managing natural resources, including biodiversity and in combating desertification and land degradation. Accordingly, the Declaration supports the promotion of environmentally sound and sustainable natural resources 
management, including the implementation of integrated land management, sustainable forest management programmes and water-use plans. The Declaration invites states and international organisations to target rural areas and households more systematically in their poverty reduction policies by integrating poverty eradication and food security as well as environmental objectives more firmly in poverty reduction strategies.

\section{European Union}

Third The European Union has been insisting on coordination between agriculture, rural economy and sustainable rural development for decades and has adopted several documents regulating these issues and setting basic principles of their future development and management. Rural development is a part of Common agricultural policy and is included in the targets set by Europe 2020: A strategy for smart, sustainable and inclusive growth.

The so-called "neo-ruralism" emerged in the European Union during the 1960s as a reaction to inconvenient position of agriculture and rural regions in industrially developed countries. It is based on the multifunctional concept of agriculture and presumption that agriculture is not the only activity rural areas can benefit from, but that it should also comprise: environment and natural landscapes conservation, food supply safety, increase of employment in rural areas, social and economic benefits, preservation of tradition and cultural heritage of rural areas etc. (Pejanović \& Vujović, 2008). Common agricultural policy (CAP) of the European Union represents a legal framework for agricultural and rural development of its Member States (Veselinović, 2009). It contains several documents pertinent to the issue of sustainable rural development and its environmental aspect. It was created in 1962, and reformed in 1992, 2003 and 2013, adapting the policy to a changing world. Moreover, the Commission's Agenda 2000, adopted in 1999, established economic, social, and environmental goals within the objectives of the CAP. Today, four main regulations govern the common agricultural policy (https://ec.europa.eu/agriculture/cap-overview_en). They were introduced by a reform in 2013 to simplify legislation and have been applied since 2014 .

CAP has always been taking into consideration the improvement of the environment and landscapes, and this issue represents an important strategic goal that Member States are supposed to implement in their national strategies of rural development (Veselinović, 2009: 61). When it comes to sustainable rural development and its environmental aspect, the most important of them is Regulation (EU) No 1305/2013 of the European Parliament and of the Council of 17 December 2013 on support for rural development by the European Agricultural Fund for Rural Development (EAFRD) and repealing Council Regulation (EC) No 1698/2005 (http://data.europa.eu/eli/reg/2013/1305/oj). The Regulation invites EU Member States to focus on priorities such as: knowledge transfer and innovation in agriculture, forestry and rural areas, farm viability, the competitiveness of all types of agriculture in all regions, promoting innovative farm technologies, sustainable management of forests, the organisation of the food chain, animal welfare, risk management in agriculture etc. It also asks them to focus on: restoring, preserving and enhancing ecosystems that are related to agriculture and forestry, the promotion of resource efficiency and the shift towards a low carbon economy in the agricultural, food and forestry sectors, and to promoting social inclusion, poverty reduction in and the economic development of rural areas (Article 4).

The Regulation's objectives also include environmental protection and climate change mitigation and adaptation. It invites Member States to limit emissions in agriculture and forestry from key activities such as livestock production, fertilizer use and to preserve carbon sinks and enhance carbon sequestration with regard to land use, land use change and the forestry sector (Article 4). Furthermore, the Regulation emphasizes that priorities for rural development in the EU should be pursued within the framework of sustainable development and environmental protection. It is also very explicit about the application of the polluter pays principle. Among 
other goals of knowledge and information sharing between farmers, rural small or medium enterprises and forest holders, is the enhancement of their abilities to increase resource efficiency and improve their environmental performance while contributing to the sustainability of the rural economy (Article 12).

When improvement of rural areas' development is concerned, the Regulation suggests the following approaches: the creation and development of new economic activity in the form of new farms, the diversification into non-agricultural activities including the provision of services to agriculture and forestry, activities related to health care, social integration and tourist activities (Article 17). The regulation points out forestry as a particularly important part of rural development, claiming that support for sustainable and climate friendly land use should include forest area development and sustainable management of forests (Article 20). In that context, the Regulation insists on granting payments to forest holders who provide environment-friendly or climate-friendly forest conservation services by enhancing biodiversity, preserving high-value forest ecosystems, improving their climate change mitigation and adaptation potential. The measures of particular importance include the reinforcement of the protective value of forests when it comes to soil erosion, maintenance of water resources and natural hazards (Article 28).

The targets set by Europe 2020: A strategy for smart, sustainable and inclusive growth (European Commission, 2010) represent an overall assessment of where the EU should be on key parameters by 2020. They are interrelated, mutually reinforcing and include: employment, research and development, climate change and energy, education and poverty and social exclusion. Europe 2020 highlights three priorities: 1) smart growth: developing an economy based on knowledge and innovation, 2) sustainable growth: promoting a more resource efficient, greener and more competitive economy and 3) inclusive growth: fostering a highemployment economy delivering social and territorial cohesion. Sustainable growth includes, among other, building a resource efficient, sustainable and competitive economy, developing new processes and technologies, including green technologies. The aim of this approach is to help the EU to prosper in a low-carbon, resource constrained world as well as to prevent environmental degradation, biodiversity loss and unsustainable use of resources.

According to Europe 2020, the European commission is therefore expected to establish a vision of structural and technological changes required to move to a low carbon, resource efficient and climate resilient economy by 2050 . One of the measures to achieve this goal includes the changes of agricultural, rural development, and maritime policies so that they address climate change. The adaptation measures these policies are supposed to introduce are based on more efficient use of resources, which would also contribute to improving global food security. The European Commission is obliged to mobilise EU financial instruments including rural development funds, as part of a consistent funding strategy that pulls together EU and national public and private funding. All these goals and guidelines confirm that there is a close and complex relationship between sustainable rural development and environmental protection, which should be taken into consideration when creating national policies and legislation.

It is also worth mentioning that the European Union has been supporting rural development in other states that are not its members for decades. Since 2007, candidate countries and potential candidates are receiving EU funding and support through the Instrument for PreAccession Assistance, or IPA. This mechanism provides help for other countries, depending on their needs and status in the process of European integrations (Janković, 2009). IPA has replaced the former pre-accession assistance instruments, i.e. the Phare, ISPA and SAPARD programmes, the specific pre-accession instrument for Turkey and the CARDS programme. One of IPA's components refers to agriculture and rural development. Current beneficiaries are: Albania, Bosnia and Herzegovina, the Former Yugoslav Republic of Macedonia, Kosovo, Montenegro, Serbia, and Turkey (https://ec.europa.eu/neighbourhoodenlargement/instruments/overview_en). 


\section{Legal framework relevant to rural development in Serbia}

Legislative framework and strategic documents regulating the area of agriculture and rural development were not fully developed in Serbia, which caused the lack of clearly defined agricultural policy and a set of long-term enhancement measures (Veselinović, 2009). On the other side, the countries that have a developed policy of regional and rural development, rural development is considered a development priority and occurs in almost all national and regional development programs (Vasilevska, 2010). In the past couple of years, the Republic of Serbia has adopted a large number of laws, strategies and other documents that regulate key issues related to agriculture and rural areas, including the following: 1) Law on Agriculture and Rural Development (Official Gazette of the Republic of Serbia, No. 41/2009, 10/2013 and 101/2016), 2) Law on Incentives for Agriculture Production and Rural Development (Official Gazette of the Republic of Serbia, No. 10/2013, 142/2014, 103/2015 and 101/2016), 3) Law on Agricultural Land (Official Gazette of the Republic of Serbia, No. 62/2006, 65/2008, 41/2009 and 112/2015), 4) Animal Husbandry Law (Official Gazette of the Republic of Serbia, No. 41/2009, 93/2012 and 14/2016), 5) Strategy of Agriculture and Rural Development of the Republic of Serbia for the period between 2014 and 2024 (Official Gazette of the Republic of Serbia, No. 85/2014), 6) National Program for Agriculture and Rural Development (Ministry of Agriculture and Environmental Protection of the Republic of Serbia, 2014: 167), 7) Forestry Development Strategy of the Republic of Serbia (Official Gazette of the Republic of Serbia, No. 59/2006), 8) Biodiversity Strategy of the Republic of Serbia (Official Gazette of the Republic of Serbia, No. 13/2011) and 9) National Strategy for Sustainable Use of Natural Resources and Goods (Official Gazette of the Republic of Serbia, No. 33/2012). The adoption of legal documents regulating agriculture and rural development was one of the obligations Serbia had to fulfil on its road towards the European integrations in order to harmonize its legislation with the standards of the European Union. Also, the World Trade Organisation requires its members to harmonise their legislative measures in the area of agriculture and their agricultural policies (Veselinović, 2009).

Having in mind the fact that rural development cannot be observed separated from environmental protection and sustainable use of natural resources, the following legislative and strategic documents should also be taken into consideration: 1) Law on Nature Protection (Official Gazette of the Republic of Serbia, No. 36/2009, 88/2010, 91/2010 and 14/2016), 2) Law on Environmental Protection (Official Gazette of the Republic of Serbia, No. 135/2004, 36/2009, 36/2009, 72/2009, 43/2011 and 14/2016), 3) Law on Strategic Estimation of Environmental Impact (Law on Strategic Estimation of Environmental Impact, Official Gazette of the Republic of Serbia, No. 135/2004 and 88/2010), 4) Law on Estimation of Environmental Impact (Official Gazette of the Republic of Serbia, No. 135/2004 and 36/2009), 5) Law on Integrated Prevention and Control of Environment Pollution (Official Gazette of the Republic of Serbia, No. 135/2004 and 25/2015), 6) Law on Air Protection (Official Gazette of the Republic of Serbia, No. 36/2009 and 10/2013), 7) Law on Waters (Official Gazette of the Republic of Serbia, No. 30/2010, 93/2012 and 101/2016), 8) Law on Forests (Official Gazette of the Republic of Serbia, No. 30/2010, 93/2012 and 89/2015), 9) Law on Spatial Plan of the Republic of Serbia between 2010 and 2020 (Official Gazette of the Republic of Serbia, No. 88/2010) and 10) Law on Planning and Construction (Official Gazette of the Republic of Serbia, No. 72/2009, 81/2009, 64/2010, 24/2011, 121/2012, 42/2013, 50/2013, 98/2013, 132/2014 and 145/2014). Finally, the fact that rural development in accordance with the principles of environmental protection has the potential to be improved via popularisation and promotion of eco-tourism, the provisions of Law on Tourism (Official Gazette of the Republic of Serbia, No. 36/2009, 88/2010, 99/2011, 93/2012 and 84/2015) should also be concerned in that context. 


\section{CONCLUSION}

It is assumed that the problems of rural development can be adequately treated within the regional development framework. This is supposed to be done through an integrated planning approach in accordance with sustainable development paradigm. Such political willingness is based on the harmonization of two traditional approaches: regional or physical planning and environmental protection. Problems of rural development require an integral approach depending on the characteristics of each individual rural area, local developmental potentials and socio-economic background. Integral approach to sustainable rural development is focused on the population, economy, environment and institutions. Rural development has to take into consideration various components such as: economic, ecological, social, energetic, cultural, religious, infrastructural and.

New forms of farm-based rural development activities are emerging and different participants compete for opportunities and resources in rural areas. For example, the interests of farmers and owners of agricultural lands might sometimes be in conflict with the interests of wildlife conservationists, eco-tourists, hobby-farmers or high quality food producers. Namely, enhancing the natural resource base could contribute to the reduction of rural poverty in cases where soil degradation is reducing yields on the farms of the poor. On the other hand, conserving natural resources might increase poverty. This refers to cases where poor rural households earn their incomes from activities such as gathering of wild flora and fauna or even depend on these as their key survival strategy. Therefore, it is essential to recognise the interests that these subjects share and try to incorporate them into national rural development policies.

Multifaceted nature of rural development requires the synergy between different fields of activity and between different levels and actors. Synergy may occur between local and regional eco-systems, specific farm styles, specific goods and services, localized food chains and specific social carriers and movements, but it also refers to the correlation between ecology and economy. This means that modern concepts of sustainable rural development demand the change of traditional organisation and management structures and relationships and the division of responsibilities, tasks, activities and funds between the state and the private sector as its important partner and their joint efforts aimed to improve local development. In this, "new paradigm of rural development", agriculture cannot be viewed as the only solution to rural poverty. On the contrary, it should be developed along with other actual and potential rural activities that are suitable to enhance the capacities of rural households and increase their incomes.

Just like other developing countries, Serbia is also facing numerous problems in the area of rural development. Some of them are present in other countries as well, whereas others represent the results of specific historical, political, economic, social and cultural circumstances. Rural areas in Serbia still seem to have certain resources for successful implementation of sustainable development concept. Nowadays, especially in the times of economic crises, agriculture, agro-industry and the potentials of rural areas play a significant role in the overall economic development of our country. However, the presence of several limiting development factors require profound structural changes and significant investment in this field.

Sustainable development of agriculture should be recognised as one of priorities of overall economic development. Such approach is in accordance with European standards, includes a multi-functional agriculture and high-quality food production as key argument for competency. For example, organic agriculture has been spreading in Serbia since 1990, but the number of agricultural lands for this type of production has been increasing in the past couple of years, thanks to support of several state and civil organisations. Another environmentally desirable potential of rural areas lays in their renewable sources of energy that can be used for the production of biomass and biodiesel. This refers to various organic materials that appear as the 
results of agricultural production. Unfortunately, it appears that this potential has not yet been fully used in Serbia and it deserves a much stronger financial and educational state support.

Education of rural population in the fields of environmental protection and sustainable use of natural resources, as well as about the application of modern technologies and approaches is also very important. However, local peasant or indigenous knowledge also has to be recognised as significantly different from standard scientific knowledge, embedded in local ecology and encoded in culture rather than theory. It is relies on the interdependent accumulation of local, natural and social resources, practices and knowledge. They are not only important for maintaining "old cultures", but also contribute to a constant renewal of knowledge systems.

Finally, normative regulation of rural development and other issues related to it is one of key preconditions for a more active role of the state in this area. It could be said that lack of adequate legislative framework contributed to the inconvenient position of rural areas in Serbia. Therefore, the adoption of allows and strategic documents harmonised with European standards represents a positive step. However, the laws and strategic documents must be implemented properly, with a more intensive monitoring, larger long-term investments in the rural areas, and multi-sectoral support. This is not possible without financial support from the budget, foreign investments and appropriate use of IPA funds.

\section{ACKNOWLEDGEMENTS}

This paper is a result of research project under the code 47011 (Crime in Serbia: Phenomenology, Risks and Possibilities of Social Intervention) of the Institute of Criminological and Sociological Research, financed by the Ministry of Education, Science and Technological Development of the Republic of Serbia.

\section{REFERENCES}

Animal Husbandry Law. Official Gazette of the Republic of Serbia, No. 41/2009, 93/2012 and $14 / 2016$.

Ashley, Caroline, Simon Maxwell. 2001. "Rethinking Rural Development." Development Policy Review, 19(4): 395-425.

Biodiversity Strategy of the Republic of Serbia, Official Gazette of the Republic of Serbia, No. $13 / 2011$.

Bogdanov, Natalija. 2007. "Mala ruralna domaćinstva u Srbiji i ruralna nepoljoprivredna ekonomija." Beograd: UNDP.

Briedenhann, Jenny, Eugenia Wickens. 2004. "Tourism routes as a tool for the economic development of rural areas-vibrant hope or impossible dream?" Tourism Management, 25(1): 71-79.

Ellis, Frank, Stephen Biggs. 2001. "Evolving Themes in Rural Development 1950s-2000s." Development Policy Review, 19(4): 437-448.

European Commission. 2010. "Europe 2020: A strategy for smart, sustainable and inclusive growth." COM(2010) 2020 final.

http://eur-lex.europa.eu/LexUriServ/LexUriServ.do?uri=COM:2010:2020:FIN:EN:PDF

Forestry Development Strategy of the Republic of Serbia. Official Gazette of the Republic of Serbia, No. 59/2006.

Janković, Snežana. 2009. "Evropska unija i ruralni razvoj Srbije." Beograd: Institut za primenu nauke u poljoprivredi.

Knickel Karlheinz, Henk Renting. 2000. "Methodological and Conceptual Issues in the Study of Multifunctionality and Rural Development." Sociologia Ruralis, 40(4): 512-528.

Law on Agriculture and Rural Development, Official Gazette of the Republic of Serbia, No. 41/2009, 10/2013 and 101/2016.

Law on Air Protection, Official Gazette of the Republic of Serbia, No. 36/2009 and 10/2013. 
Law on Agricultural Land, Official Gazette of the Republic of Serbia, No. 62/2006, 65/2008, $41 / 2009$ and $112 / 2015$.

Law on Environmental Protection, Official Gazette of the Republic of Serbia, No. 135/2004, 36/2009, 36/2009, 72/2009, 43/2011 and 14/2016.

Law on Estimation of Environmental Impact, Official Gazette of the Republic of Serbia, No. $135 / 2004$ and 36/2009.

Law on Forests, Official Gazette of the Republic of Serbia, No. 30/2010, 93/2012 and 89/2015.

Law on Incentives for Agriculture Production and Rural Development, Official Gazette of the Republic of Serbia, No. 10/2013, 142/2014, 103/2015 and 101/2016.

Law on Integrated Prevention and Control of Environment Pollution, Official Gazette of the Republic of Serbia, No. 135/2004 and 25/2015.

Law on Nature Protection, Official Gazette of the Republic of Serbia, No. 36/2009, 88/2010, $91 / 2010$ and $14 / 2016$.

Law on Planning and Construction, Official Gazette of the Republic of Serbia, No. 72/2009, 81/2009, 64/2010, 24/2011, 121/2012, 42/2013, 50/2013, 98/2013, 132/2014 and $145 / 2014$.

Law on Spatial Plan of the Republic of Serbia between 2010 and 2020, Official Gazette of the Republic of Serbia, No. 88/2010.

Law on Strategic Estimation of Environmental Impact, Official Gazette of the Republic of Serbia, No. 135/2004 and 88/2010.

Law on Tourism, Official Gazette of the Republic of Serbia, No. 36/2009, 88/2010, 99/2011, 93/2012 and 84/2015.

Law on Waters, Official Gazette of the Republic of Serbia, No. 30/2010, 93/2012 and 101/2016.

Marsden, Terry, Jo Banks, Henk Renting, Jan Douwe Van der Ploeg. 2001." The Road Towards Sustainable Rural Development: Issues of Theory, Policy and Research Practice." Journal of Environmental Policy \& Planning, 3(2): 75-83.

Ministerial declaration on promoting an integrated approach to rural development in developing countries for poverty eradication and sustainable development, $A 58 / 3 / \operatorname{Rev} 1$ $\begin{array}{llll}\text { adopted } & \text { on } & 3 & \text { July }\end{array}$ http://www.un.org/esa/coordination/Alliance/documents/website/ministerial\%20declarati on.pdf

Ministry of Agriculture and Environmental Protection of the Republic of Serbia. 2014. "Republic of Serbia IPARD Programme for 2014-2020." Belgrade: Ministry of Agriculture and Environmental Protection of the Republic of Serbia.

National Strategy for Sustainable Use of Natural Resources and Goods, Official Gazette of the Republic of Serbia, No. 33/2012.

National Sustainable Development Strategy, Official Gazette of the Republic of Serbia, No. $57 / 2008$.

Overview - Instrument for Pre-accession Assistance. https://ec.europa.eu/neighbourhoodenlargement/instruments/overview_en

Pejanović, Radovan. 2007. "Dileme oko koncepta našeg agrarnog razvoja." Agroekonomika, 36(36): 6-24.

Pejanović, Radovan, Slavoljub Vujović. 2008. "Ruralni razvoj i agroturizam." Agroekonomika, 37-38(37-38): 5-14.

Pejanović, Radovan. 2009. "Razvojni problemi poljoprivrede Republike Srbije." Agroekonomika, 41-42(41-42): 5-23.

Reardon, Thomas, Stephen Vosti. 1995. "Links between Rural Poverty and the Environment in Developing Countries: Asset Categories and Investment Poverty." World Development, 23(9): 1495-1506.

Regulation (EU) No 1305/2013 of the European Parliament and of the Council of 17 December 2013 on support for rural development by the European Agricultural Fund 
for Rural Development (EAFRD) and repealing Council Regulation (EC) No 1698/2005. http://data.europa.eu/eli/reg/2013/1305/oj

Ristić, Lela. 2013. "Strategijsko upravljanje održivim ruralnim razvojem u Republici Srbiji." Ekonomski horizonti, 15(3): 229-243.

Scheyvens, Regina. 1999. "Ecotourism and the empowerment of local communities." Tourism Management, 20(2): 245-249.

Strategy of Agriculture and Rural Development of the Republic of Serbia for the Period between 2014 and 2024, Official Gazette of the Republic of Serbia, No. 85/2014.

UN General Assembly. 2015. Transforming our World : the 2030 Agenda for Sustainable Development, $\quad 21 \quad$ October $2015, \quad$ A/RES/70/1. http://www.refworld.org/docid/57b6e3e44.html

Van der Ploeg, Jan Douwe, Henk Renting, Gianluca Brunori, Karlheinz Knickel, Joe Mannion, Terry Marsden, Kees de Roest, Eduardo Sevilla-Guzmán, Flamina Ventura. 2000. "Rural Development: From Practices and Policies towards Theory." Sociologia Ruralis, 40(4): 391-408.

Vasilevska, Ljiljana. 2010. "Rural development and regional policy - conceptual framework." Facta Universitatis Series: Architecture and Civil Engineering, 8(3): 353-359.

Veselinović, Janko. 2009. "Normativno regulisanje ruralnog razvoja kod nas i u uporednom pravu." Agroekonomika, 41-42(41-42): 53-68.

World Commission on Environment and Development. 1987. "Report: Our Common Future." http://www.un-documents.net/our-common-future.pdf

\begin{tabular}{|l|l|}
\hline \multirow{2}{*}{ Article history: } & Received: January 13, 2018 \\
\cline { 2 - 2 } & Accepted: June 7, 2018 \\
\hline
\end{tabular}




\title{
Social Responsibility of Banks in the Function of Comparative Advantage on the Market
}

\author{
Milica Raičević $^{1 *}$ | Dijana Medenica Mitrović ${ }^{2}$ \\ ${ }^{1}$ Faculty of Business Studies “Montenegro Business School”, Mediterranean University, Podgorica, Montenegro \\ 2 Faculty for Business Management Bar, Bar, Montenegro
}

\begin{abstract}
The business operation of companies is not neutral and is not perceived any more in terms of profitable operations, but also in terms of whether it is beneficial for the society. Social responsibility contributes to improving relationships with key stakeholders, thus contributing to the long-term sustainability of the company. The paper points out to the positive link between corporate social responsibility (CSR) and the reputation of the bank. Without CSR, neither the improvement nor the expansion of banking operations is possible. The aim is to point out that profit and CSR are not opposed categories and that the CSR of banks represents a strong comparative advantage on the market. The paper gives a theoretical and practical overview of the concept of corporate social responsibility (CSR), with a focus on the banking sector. In the theoretical part, the term CSR is defined, as well as its significance and special features regarding the application in the banking sector. The empirical part deals with the study of the characteristics of the Montenegrin banking sector, its characteristics in terms of CSR. The empirical part includes the qualitative analysis, based on the data available on the official sites of banks operating in Montenegro. Based on the collected Internet data, an analysis of the factual situation was carried out, conclusions were given and recommendations have been made for the implementation of the CSR concept with a view of improving the competitive position of banks on the market. Through qualitative analysis of the available data, the advantages and disadvantages of corporate social responsibility of banks in Montenegro were considered, as well as which CSR activities are most represented and which still have the capacity to be improved and involved in the marketing strategies of the banks in Montenegro.
\end{abstract}

Key words: social corporate responsibility, banks, reputation, marketing

JEL Classification: N20, G20

\section{INTRODUCTION}

The turbulence of the environment, market changes that represent the process today, not just the business event as they once did, have led to the need for companies to re-examine themselves and to supplement their business strategy in order to gain competitive advantage in the market. In order to gain a competitive advantage they should focus on the people, that is, the need to increase the number of people who use their products and services or more simply believe in them. In order to be successful in a dynamic services market companies must delivered superior value to target customers who become more demanding, and choose products/services rationally, analysing relation between price and quality. The competitiveness of companies in the financial sector is largely based on fostering customer loyalty, integrating

\footnotetext{
*E-mail: milica.raicevic@unimediteran.net
} 
various communication channels, reducing operating costs and good risk management (Domazet, Stošić and Hanić, 2016). In the last ten years, in the literature, as well as in the practice, the concept of social responsibility has started to develop, which focuses on the support to the community in which the business operations are carried out, and in return, these companies are recognized by the community as the companies which should be trusted, which is one of the ways in which the companies can contribute to their growth and their competitive advantage. Banks, as a specific phenomenon by itself which has a specific way of generating profit, have realized that they have to incorporate the concept of social responsibility into their business strategy, in order to differentiate and gain a competitive advantage in the banking sector, which is characterized by an increasing number of banks and tougher competition in the financial market.

The paper views the concept of social responsibility, the banks in Montenegro, as well as the implementation or introduction of this concept in their operations. Moreover, a positive correlation between corporate social responsibility (CSR) - reputation of the bank has been pointed out. The Without the social responsibility of banks, it is not possible to improve or extend the banking operations. The aim is to point out that profit and CSR are not opposed categories and that the CSR of banks represents a serious comparative advantage on the market.

The initial hypothesis: The application of the concept of social responsibility is an important factor for achieving competitive advantage and strengthening the position of banks in the financial market, all through the creation of services that will improve and expand banking activities, to create satisfied consumers who are loyal.

Auxiliary hypotheses are:

1. The willingness of banks to invest in CSR activities will increase the confidence in banks by customers and the community

2. Developing awareness of the importance of CSR for company business and training and inclusion of employees in CSR activities provides for a higher level of business and better reputation

3. Socially responsible activities address the problem for which the state does not have sufficient financial resources, which also affects the strengthening of the reputation of the bank

4. Improving the business environment creates the conditions for developing the competitiveness of banks and strengthening their position in the financial market, and therefore profit.

The paper gives a theoretical and practical overview of the concept of CSR and its application in the banking sector. In the theoretical part, the term CSR is defined, its significance and specific qualities related to the application in the banking sector. The empirical part deals with the study of the characteristics of the Montenegrin banking sector, its features in terms of CSR. The empirical part covers qualitative analysis, on the basis of the data available from the official websites of the banks operating in Montenegro. On the basis of the data collected from the Internet, an analysis of the factual situation has been conducted, conclusions have been drawn and recommendations have been made for the application of the CSR concept in order to improve the competitive position of banks on the market. Through the qualitative analysis of the available data, the advantages and disadvantages of social responsibility of banks in Montenegro have been studied. It has been analysed which CSR activities are the most prominent, and for which there is still the space to be improved and involved in the marketing strategies of banks operating in this area.

In the end, it has been pointed out that the awareness of the benefits the CSR brings to the company has not still been developed in Montenegro. The socially responsible practice is often perceived as an unprofitable and impractical activity. In recent years, in the banking sector, socially responsible activities are growing in importance and have a tendency towards growth. 
The social responsibility of banks is significant for the Montenegrin economy and society, because socially responsible banking activities contribute to the improvement and advancement of the existing situation in certain segments which the country has insufficient resources to support. Banks carry out their socially responsible activities through activities in the fields of education, health care, culture, sports, environment protection, and work with people with disabilities. In conclusion, the banks have a dual role, they are both promoters of socially responsible behaviour and institutions investing in those areas of vital importance, for which the state does not have enough resources. The CSR of banks represents a serious comparative advantage in the market, because the banks that implement it (especially foreign banks) send their clients a clear message that they are ready to stay in Montenegro and actively engage in solving problems at both the local and the national level.

\section{THEORETICAL ASPECTS OF SOCIAL RESPONSIBILITY OF BANKS IN MONTENEGRO}

\section{Defining the concept of corporate social responsibility}

Social responsibility is now perceived as an inevitable part of the company's operations and one of the market differentiation options. In this context, social responsibility or corporate social responsibility (according to the World Business Council for Sustainable Development) can be seen as "the commitment of business units to contribute to sustainable economic development, cooperation with employees, their families, the local community and society as a whole aimed at improvement of the quality of their lives"(Saraiva and Serrasqueiro, 2007). This would mean that the concept of social responsibility does not perceive as the opposing sides, on the one hand, the people, the community and the environment, and on the other hand, the economic goals of the company. The concept of social responsibility would mean that the company assumes responsibility for the impact of its own activities on all the stakeholders of the company, as well as on the environment (Zelenović, 2015). Moreover, it should be emphasized that CSR is not the same for every company, but that the business operations according to this principle depends on the size of the company, the economic region, the market and the actual operations of the company.

As noted, the operations based on the corporate social responsibility principle connect and enhance the relationships between the company, stakeholders and the environment, and combines them into a single whole that generates benefits both for the company itself and for the meeting of the current needs of future generations. So the most famous model regarding the CSR is the model of the pyramid presented by Caroll (1996), according to which if the company is to be socially responsible, then it needs to be financially stable (to be profitable), then legally responsible (to respect the laws of the state and markets), then ethically responsible (to operate in accordance with the moral and ethical norms of the society, community and the market) and ultimately to have a philanthropic responsibility (to be a good citizen).

When we talk about when the concept of social responsibility dates back, we could say that, from a historical point of view, it dates back to the thirties of the last century, and as the subject of research of experts and interested individuals, somewhat later, sometime to the nineties, when companies accept the contemporary concept of social responsibility and implement it into their business strategy so that the activities they carry out create value for the company's owners, on the one hand, and for a wider community, on the other.

\section{Significance and characteristics of corporate social responsibility}

Numerous questions are raised regarding the concept and implementation of corporate social responsibility. Some of them are related to the actual implementation of this concept in the company's operations and they relate to whether social responsibility is cost-effective or not and whether it should be considered as a cost or as an investment (Stojanovi-Aleksić and allies 
2016). The given questions cannot be answered either with yes or no, but the answers require perceiving the things from different angles. The concept of social responsibility can be viewed from the aspect of the impact that the company operating in accordance with the given concept has on the enterprise and the society. This would mean that the responsible behaviour earns praise, that is, produces positive effects with the public which can be seen in the long run and can create a positive image or improve the existing one. Thus, the sense of security and confidence is created among the interested individuals and groups, which creates a positive effect on the actual operations of the company. This means that the concept of social responsibility creates a positive effect on the company through the activities that contribute to the positive image, and the image creates confidence among the stakeholders, which contributes to the increase of the value of company's shares, greater market share, competitive advantage etc. The study carried out in the USA has shown that the factors related to the social responsibility have almost the same effect on the company's reputation as some traditional factors such as quality, price, usage etc. (Stojanovi-Aleksić and allies 2016)

It should also be taken into account that there is another aspect that reflects the importance of social responsibility, and that is the reporting on corporate social responsibility which should be included in the results and reporting on the company's overall business operations.

When we talk about the activities, that is, the areas that the concept of social responsibility entails, we would say that it is the promotion of social goals (humanitarian work), the interconnection between marketing activities and social goals (part of the revenue is allocated for solving the problems of vulnerable groups), volunteer work (voluntary work aimed at supporting and actively participating in a community-run activity) and corporate philanthropy (the company's contribution through humanitarian activities) (Stojanovi-Aleksić and allies 2016).

\section{Specific phenomenon of social responsibility in the banking sector}

The above mentioned prompted us, when talking about social responsibility, to think first about the relationship between CSR and profit-making companies, which perceive this concept as a way of contributing to the community, on the one hand, and of gaining greater competitive advantage, on the other hand. The banks generally did not have a need for such a concept. This is due to the fact that they are independent financial institutions that take care of their finances independently, as well as the fact that they are intermediaries in the economy and have no need to care about the profit. However, due to the development of the market, increase in the number of participants in the banking market and increase and creation of new banking services, banks had to find a way to improve their reputation, develop trust among customers, restore the trust through various activities that would be receptive to people's eyes and ears. The assets of the company are not worth without customers, the task of managing services marketing is not only to attract new, but also to retain existing customers. New customers can be attracted only by delivering superior service, the role of marketing is to create a superior offer and ensure customer satisfaction, but also to anticipate the future needs of its clients, only satisfied customers can be loyal to a given organisation (Hanic, Domazet, 2012).Thus the banks have realized that the concept of social responsibility provides an opportunity for expansion and improvement of their business operations. They can incorporate this concept into their defined strategy and thus, through the CSR activities, gain competitive advantage in the banking market. By implementing socially responsible activities, the banks become an active part of the community in which they operate (Zelenović, 2015) through the following:

- Promotion of social goals - through a financial contribution or other types of contribution to develop or solve a particular social goal,

- General Well-Being Marketing - when a certain amount of revenue is allocated for the achievement of a social goal 
- Corporate Social Marketing - assistance in development, implementation of campaigns which contribute to raising the awareness of the health, the sick, environmental protection ...,

- Corporate Philanthropy - making direct contributions to a charitable or social activity,

- Community Volunteer Work - voluntary work of employees and partners,

- Socially Responsible Business Practice - adopting and implementing the business practice that supports a social goal which should improve the life of the community (both the people and the environment) (Kotler, Li, 2009).

Based on the above, market changes and behaviour in the banking sector have led to the situation where the banks behave in the following way (Vunjak, Kovačević, 2006):

- Customer orientation because he/she is the most important person

- The client is the purpose of the banking business

- Respecting the wishes and demands of the clients

- A higher marketing concept

- Customer service quality.

The motive for introducing the concept of social responsibility appears at different levels (Zelenović, 2015):

- Internal ethics - processes in banks and

- External ethics - consequences of banking actions.

\section{PRACTICE OF SOCIAL RESPONSIBILITY OF THE BANKS IN MONTENEGRO}

\section{The empirical framework of social responsibility of the banks in Montenegro}

Banks, as independent financial institutions, have focused on the care about their finances until recently. The Bank is perceived solely as a recipient and provider of banking services, whose employees dominate the clients, without the adequate system of rewards and without paying a particular attention to the competition and customer requirements. The turbulent environment, the saturation of consumers by marketing advertising of various forms, has imposed the need for incorporating the socially responsible operations in the strategies of banks, as the necessary prerequisite for acquiring and maintaining the competitive advantage. They must not be focused solely on profit, but must be socially responsible, and take care of the environment. This raises the question of whether company can be both environmentally and socially responsible and profitable at the same time (Domazet, Kovačević, 2018).

The whole community benefits through the activities of corporate social responsibility and the clients are becoming aware of this. By associating their products and services with the solving of a particular social problem, the banks do their promotion and encourage customers to buy their products or services. Banks can demonstrate corporate social responsibility by providing the financial resources for raising awareness of a social problem, encouraging campaigns for behavioural change, engaging in local initiatives, humanitarian actions, financing and implementing the business practice for environmental protection or improvement of community life.

All of these activities can be carried out by the bank itself and in cooperation with public sector partners, profit and non-profit organizations. Moreover, the bank encourages and supports both its employees and partners to help local organizations and actions through voluntary work. Implementation of CSR activities is increasingly under pressure, both internal and external, to apply a strategic approach. The bank needs to choose what it will focus on and how to link its philanthropic and other initiatives to its business goals and tasks. The goal of 
investing in various forms of socially responsible strategies is the strengthening of the bank's reputation. Through its reputation, the bank creates barriers to its competitors, sends a message that its services are of high quality, improves its market position, which contributes to profit increase. At the level of the economy, such operations encourage increased competitiveness and transparency in business, encourages trust and partnerships with the target public. The goal of reputation is not that a bank is liked but to create its value through business success and the solving of community problem which the state cannot solve alone.

Changes in the way of thinking and behaviour have led to more customer-orientated banks today, respect for customers' wishes and demands, introduction of a higher marketing concept and an increase in service quality.

Today, even conventional banks are participating in the actions that are of general welfare to the community. Some of these activities are as follows: local scholarships and sponsorships, financing in the field of sports, health care, culture, more affordable housing loans, financing of some traditional events in the community, etc.

Although the positive effect of applying the CSR concept in the banking operations has already been recognized, this concept is still inadequately implemented in a wider scope in Montenegro, although the trend towards the growth of CSR activities has been present in recent years. The reason for this can be found in the still underdeveloped awareness of the benefits of socially responsible practice, since such practice is often perceived as unprofitable and impractical experience. The common approach to corporate social responsibility is usually limited, defensive and unrelated to the actual strategy of the bank. The CSR activities should be aimed at enhancing the relationship between employees and customers (as key stakeholders) so that they do not abandon the bank.

According to the official data of the Central Bank of Montenegro, 15 licensed banks operate in Montenegro. The data on corporate social responsibility of banks is available on the official websites of seven Montenegrin banks, which suggest that a little less than half of the banks have recognized the importance of informing the stakeholders of this aspect of bank operations. The CSR data is available for the following banks:

1. Societe Generale bank Montenegro AD

2. Prva banka Crne Gore AD Podgorica

3. NLB Banka AD Podgorica

4. Addiko Bank AD Podgorica

5. ERSTE Bank AD Podgorica

6. Crnogorska komercijalna banka AD Podgorica member of OTP Group

7. Hipotekarna banka AD Podgorica

On the basis of available data on the official websites of Montenegrin banks, it can be concluded that socially responsible activities are mainly focused on the fields of health care, education, sports, culture and the promotion of environmental protection.

\section{Analysis of the state of corporate social responsibility of the banks in Montenegro}

Analysis of the state of corporate social responsibility of the banks in Montenegro was made on the basis of secondary data, available on the official websites of the banks operating in our territory. Below is an overview of the key objectives and activities of the seven banks, which publish the information on their CSR activities on their websites.

Societe Generale Montenegro Bank indicates, as the objective of its CSR activities, the support for projects in the field of health care, education and culture which are useful for citizens and society over a longer period of time. The social community has acknowledged the efforts of this Bank and in 2011, 2012 and 2015 Societe Generale Montenegro, as a socially 
responsible company, was given the ISKRA Award for philanthropy for the overall contribution of the Bank to the Montenegrin society and for its contribution to inclusive education. The Bank is also the winner of the Naturally Equal Award received for the best practice in achieving gender equality in Montenegro (http://www.societegenerale.me/mne/o-nama/o-societegenerale-banci-montenegro, accessed on 17.03.2018.).

The activities of the Bank focused on healthcare activities included cash donations for the purchase of necessary resources for the Montenegro Clinical Centre and the Institute for Children's Diseases, as well as for procurement of medical and sanitary equipment for healthcare institutions, primarily for health care centres and general hospitals in the territory of Montenegro. In this way, the Bank contributes to the creation of better conditions for the strengthening of health care and the care about the public health.

The Bank is also active when it comes to monetary donations and cooperation with nongovernmental organizations dealing with the problems of children with developmental disturbances, people with disabilities, children suffering from cancer, as well as women victims of violence and juvenile mothers. With these donations, the Bank draws attention to this group of women and children and actively participates in an effort to improve the position of women and children in the Montenegrin society.

Societe Generale Bank also directs its socially responsible activities towards the support for inclusive education (donations to the stimulation room in elementary schools, financing instruction manuals for improvement of the teaching process within the inclusive education). Through donations for educational tools in kindergartens, the construction of children's playgrounds, presents for pupils who walk to school from rural areas, the concern is shown for young people and improvement of conditions in educational institutions. The Bank also organized a student competition on the topic of Corporate Social Responsibility, which contributes to the development of awareness of the importance of corporate social responsibility among this target group.

Within the activities aimed at environmental protection, the Bank supported the activities of greening of certain parts of the Capital. Another action with the same goal was the purchase of electric bicycles for employees and clients.

Numerous activities include humanitarian aid for the most deprived families, donations for the Library of the blind, as well as numerous sponsorships for art exhibitions of Montenegrin artists.

Prva banka Crne Gore has actively participated in the realization of socially beneficial projects since the very beginning of its existence. It is recognized by its support for projects of national significance in the field of health care, culture, sports, as well as support for humanitarian and other projects that have an impact on raising the quality of life of the citizens in Montenegro (http://www.prvabankacg.com/o-nama/drustvena-odgovornost/, accessed on 17.03.2018.).

Some of these projects by which Prva Banka Crne Gore confirms its strategic commitment to corporate social responsibility include: The Ulcinj's greening project, sponsorship of the women's handball team of Montenegro at the World Championship in Denmark, a donation for the Internal ward of the Bar Hospital.

NLB Montenegro bank promotes its socially responsible operations through sponsorships or donations to cultural, sports and entertainment events as well as environmental protection projects. The largest and most significant sponsorship projects of NLB Banka are: sponsorship of the Budućnost Basketball Club, the AS Tennis Club, the main sponsor of the National Parks of Montenegro, which has been its partner since November 2010 within the project 'Obradujmo prirodu' (Make the Nature Happy), which contributes to raising awareness of the importance of environmental protection and conservation of protected natural areas for future generations (https://www.nlb.me/me/nlb-banka/opste/sponzorstva-i-donacije, accessed on 17.03.2018.). 
For several years, Addiko Bank AD Podgorica has been allocating funds in a planned manner, within its budget, to support the local community, where it carries out its activities, through the support for the work of educational and healthcare institutions, and events aimed at promoting and preserving social values through the fields of culture, arts, non-commercial sports activities (https://www.addiko.me/o-nama/drustvena-odgovornost/sponzorstva-idonacije/, accessed on 17.03.2018.). The most significant activities include: donations to children and adolescents with developmental disturbances; cooperation with non-governmental organizations and primary schools to support children with autism spectrum disorders; donations to children suffering from cancer; donation to the Institute for Children's Diseases for the supply of equipment for the ORL ward. In cooperation with the Red Cross, it participates in humanitarian actions for socially vulnerable citizens and in voluntary blood donation activities. Among numerous activities the following are also worth mentioning: donations to the Fire Department in Tivat; assistance for the purchase of equipment for the national team of the Special Olympic Games of Montenegro; baskets for the school gym in Žabljak; equipment for primary and secondary schools in Kotor and Tivat; procurement of exercise equipment in the gym of the junior team of the "Jadran" water polo club; a donation aimed at improving the social inclusion of children and youth with developmental disturbances and people with disabilities; donations of children's books to libraries in Podgorica and kindergartens in Kotor and Tivat; sponsorship of the Sea Dance Festival. As a modern and practical bank focused on customers and their needs, Addiko has also provided the festival's visitors with various opportunities to make simple financial transactions on-site. The Sea Dance Festival payment card and the Addico Bank card was the official payment instrument at the Sea Dance Festival, and Addiko Bank has also provided an ATM for cash withdrawals for all visitors (https://www.addiko.me/onama/drustvena-odgovornost/sponzorstva-i-donacije/, accessed on 17.03.2018.). What seems interesting is the fact that all the activities listed on the website of Addiko Bank were conducted in the period from November 2016 to December 2017.

Erste Banka actively and consistently contributes to the re-building of the value system, the development of society and culture in the country by initiating, acknowledging and providing organizational and financial support to the activities, projects, organizations and institutions acting in the same direction. Erste Banka gives its contribution to: the culture and arts, education, sports, social inclusion and environmental protection (https://www.erstebank.me/sr_ME/footer-stanovnistvo/o-banci/Sponzorstva-i-donacije accessed on 17.03.2018.). One of the ongoing programmes listed on the website refers to the Best of South East Programme: Study in Graz -Development and Further Education programme, as well as international work experience for talented and dedicated graduates and students from Montenegro, Bosnia and Herzegovina, Croatia, Macedonia, Slovenia and Serbia.

Crnogorska komercijalna banka bases its corporate social responsibility on supporting independently or as a partner the realization of projects in the field of culture, arts, science and sports.

Aware of the importance of entrepreneurial initiative in culture, CKB has supported the representative editions of the CID publishing house (economic, literary, legal, anthropological, historical) which has published important studies from the history, culture, nature of Montenegro, as well as numerous capital translations (http://www.ckb.me/marketing-ipr/marketing-i-pr.69.html accessed on 17.03.2018.).

CKB sponsors or participates in the organization of various events (concerts, Mimosa Festival, World Savings Day), gives donations in the field of health care, education and science, paying special attention to children and young people, through the scholarships to the best, but also through the CKB donations to the UNICEF projects. The support for sports clubs in football, basketball, handball, karate, and cooperation with the Montenegrin water-polo national team are some of the CSR activities of Crnogorska Komercijalna Banka. CKB has recognized the importance of financing in the field of cinematography (Film Festival Hercegfest) and arts. 
Moreover, for the first time in Montenegro CKB ensures the financing of renewable energy sources aimed at continuous improvement of efficient and sustainable economic, social and ecological environment (http://www.ckb.me/marketing-i-pr/marketing-i-pr.69.html accessed on 17.03.2018.).

Hipotekarna banka AD Podgorica is the winner of the special award "Iskra" for corporate philanthropy in 2016. The award has recognized the contribution and importance of corporate social responsibility of Hipotekarna banka AD Podgorica, which has several directions: investment in health care improvement, investment in culture, care for the elderly, investment in youth education and general contribution to the community. Some of the CSR activities of Hipotekarna banka are: donations of books to educational institutions in Montenegro; scholarships and the provision of international practice to the best students; procurement of reanimation vehicle for the needs of the Institute for Emergency Medical Assistance; together with the partners, the donations of vehicles for the transportation of patients on dialysis of the Montenegrin Clinical Centre; participation in the donation to the Clinic for Gynecology and Obstetrics; in cooperation with the non-governmental sector, the donations to the Nursery Home in Bijelo Polje; the general sponsorship of the Montenegrin National Theatre; donations of funds for the construction of a swimming pool in Nikšić; sponsorship of the Made in NY Jazz Festival; organization of panel discussions "Live globally, work locally"(http://hipotekarnabanka.com/o-banci/vijesti accessed on 17.03.2018.).

\section{Results of empirical research}

The overall goal of sustainable development is the long-term sustainability of economy and the environment, which will be achived by integrating economic, environmental and social aspects of the decision-making process (Domazet, Kovačević, 2018). Adequate socially responsible activity of banks contributes significantly to the improvement and advancement of the existing situation in those segments of society and the local community which the state has either insufficient interest or resources to support. From the previous analysis of the state of corporate social responsibility of banks in Montenegro, it can be seen that some banks are aware of their social responsibility, which is demonstrated through financial investments in certain activities. Some of the most prominent activities include: inclusive education, work with people with disabilities, health care, education, sports, culture, environmental protection, work with the youngest, which are all segments of our society, for which insufficient funds are allocated from the state budget.

Table 1. CSR activities of the banks in Montenegro

\begin{tabular}{|l|c|c|c|c|c|c|c|}
\hline $\begin{array}{l}\text { CSR Bank } \\
\text { activity }\end{array}$ & $\begin{array}{c}\text { Societe } \\
\text { Generale } \\
\text { banka MNE }\end{array}$ & $\begin{array}{c}\text { Prva } \\
\text { banka } \\
\text { Crne Gore }\end{array}$ & $\begin{array}{c}\text { NLB } \\
\text { bank } \\
\text { MNE }\end{array}$ & $\begin{array}{c}\text { Addiko } \\
\text { bank }\end{array}$ & $\begin{array}{c}\text { Erste } \\
\text { bank }\end{array}$ & $\begin{array}{c}\text { Crnogorska } \\
\text { komercijalna } \\
\text { banka }\end{array}$ & $\begin{array}{c}\text { Hipotekarna } \\
\text { banka }\end{array}$ \\
\hline Health care & $\mathrm{x}$ & $\mathrm{x}$ & & $\mathrm{x}$ & & & $\mathrm{x}$ \\
\hline $\begin{array}{l}\text { Education and } \\
\text { science }\end{array}$ & $\mathrm{x}$ & & & $\mathrm{x}$ & $\mathrm{x}$ & $\mathrm{x}$ & \\
\hline $\begin{array}{l}\text { Inclusive } \\
\text { education }\end{array}$ & $\mathrm{x}$ & & & $\mathrm{x}$ & & & \\
\hline Social inclusion & $\mathrm{x}$ & & & $\mathrm{x}$ & $\mathrm{x}$ & & $\mathrm{x}$ \\
\hline Culture & $\mathrm{x}$ & $\mathrm{x}$ & $\mathrm{x}$ & $\mathrm{x}$ & $\mathrm{x}$ & $\mathrm{x}$ & $\mathrm{x}$ \\
\hline Sports & $\mathrm{x}$ & $\mathrm{x}$ & $\mathrm{x}$ & $\mathrm{x}$ & $\mathrm{x}$ & $\mathrm{x}$ & \\
\hline Arts & $\mathrm{x}$ & & & $\mathrm{x}$ & & $\mathrm{x}$ & $\mathrm{x}$ \\
\hline $\begin{array}{l}\text { Environmental } \\
\text { protection }\end{array}$ & $\mathrm{x}$ & & $\mathrm{x}$ & & $\mathrm{x}$ & $\mathrm{x}$ & \\
\hline
\end{tabular}

Source: authors' analysis 18.03.2018. 
Banks have a dual role: the role of promoters of socially responsible behaviour and institutions investing in those areas of vital importance for community development, for which the state does not have enough resources. In this way, the banks are directly involved and become a partner to the country in solving strategic social issues, both at the local and the national level.

Banks also have some benefits from CSR initiatives, namely: building a strong corporate reputation, contributing to overall business goals, attracting and retaining motivated workforce, supporting marketing goals, establishing strong relationships in the community, etc., which contributes to the comparative advantage of certain banks in the market.

Given that these activities are just some of those available to the banks in the area of corporate social responsibility, we hope that corporate social responsibility will develop in Montenegro in the forthcoming period, and that the banks will also be in a position, through the appropriate selective credit and interest rate policy, as well as the establishment of special funds, to have a direct impact on the companies to behave in a more responsible manner.

Given that Montenegrin banks are predominantly in foreign ownership and that the CSR represents a serious comparative advantage on the market, the foreign banks which implement the CSR send their customers a clear message that they are ready to stay in Montenegro and actively engage in solving problems both at the local and the national level.

\section{CONCLUSION}

As the conclusion of the paper and the conducted research, it is suggested that the concept of social responsibility and supplementing the bank's business strategy with it, can have multiple benefits for the bank itself, i.e. its competitive advantage in the banking sector, as well as for the improvement of the community and hence greater customer satisfaction. By introducing this concept, a positive image is built in the market, and thus a greater degree of trust is created in the operations of the bank by all interested individuals and groups.

The paper analyses the concept of corporate social responsibility, its positive effect on the above-mentioned entities, the introduction of this concept into the strategy and business policy, the specific phenomenon of the bank and its operations, and the contributions that the Introduction of this concept makes both for the bank and for all stakeholders of the bank.

The results obtained by empirical research in Montenegro indicate that banks carry out their socially responsible activities through the activities in the fields of education, healthcare, culture, sports, environmental protection, and work with people with disabilities. The conclusion is that banks have a dual role, they are both promoters of socially responsible behaviour and institutions that invest in those areas of vital importance, for which the state does not have enough resources. It was then concluded that the CSR of banks constitutes a serious comparative advantage in the market, since the banks that implement it (especially foreign banks) send their clients a clear message that they are ready to stay in Montenegro, and actively engage in solving problems both at the local and the national level.

The contribution of this paper is reflected in the fact that through a qualitative analysis a breakdown has been given of the activities and areas in which the CSR of banks in Montenegro is present. An analysis of CSR activities can be helpful to decision-makers in the marketing sector of banks in deciding how to use CSR as one of the leverages for gaining the comparative advantage in the market. We have also defined in the paper what characterizes the CSR of the banks in Montenegro, what are the advantages and what are the shortcomings in the past CSR practice of banks, and in which direction the CSR of banks should be improved. The contribution of the paper is also reflected in the analysis of what is the extent of the impact of CSR activities on the generation of a higher profit of banks.

Moreover, new opportunities for future research have been opened, and one of them concerns the strategies that banks use in the implementation of corporate social responsibility. 


\section{REFERENCES}

Carroll, Archie. 1996. Business and Society: Ethics, Sustainability and Stakeholder management, Cincinatti Ohaio: South-Western Collage Publishing

Domazet, Ivana, Đokić Ines and Milovanov Olja. 2018. "The Influence of Advertising Media on Brand Awareness", Management: Journal of Sustainable Business and Management Solutions in Emerging Economies, 23(1):13-22.

Domazet, Ivana, and Kovačević Milica. 2018. "The Role of Green Marketing in Achieving Sustainable Development", International Monograph "Sustainable growth and development in small open economies" Institute of World Economics, Budapest, Hungary: 57-73.

Domazet, Ivana, and Stošić Ivan. 2013. "Strengthening the competitiveness of Serbian economy and the corporate market restructuring", Economic Analysis, 46(3/4):108-124.

Domazet, Ivana, Stošić Ivan, and Hanić Azra. 2016. „New technologies aimed at improving the competitiveness of companies in the services sector”, International Monograpf „Europe and Asia: Economic Integration Prospects". CEMAFI International, Nice, France: 363-37

Hanić, Hasan, and Domazet Ivana. 2012. "Specifičnosti marketinga finansijskih organizacija", Marketing 43(1): 3-14

Kotler, Ph., and Li Nensi. 2009. Korporativna društvena odgovornost, Beograd, Hesperiadeu

Kundid, Ana. 2012. "Društveno odgovorno poslovanje banaka u Republici Hrvatskoj", Ekonomska misao i praksa dbk, God XXI, 2: 497-528

Saraiva, P.P., and Serrasqueiro Z.M.S. 2007. "Corporate Sustainability in the Portuguese Financial Institutions", Social Responsibility Journal, 3(2): 82-94

Stojanović-Aleksić, Vesna, Erić Nielsen Jelena, and Bošković Aleksandra. 2016. „Društvena odgovornost u bankarskom sektoru: Iskustva iz Republike Srbije“, Bankarstvo, 45(2): 34-55

Vuković, Vlastimir and Domazet Ivana. 2013. "Problematični krediti i sistemski rizik: komparativna analiza Srbije i tranzicionih zemalja", Industrija, 41(4): 59-74.

Vunjak, Nenad, and Kovačević Ljubomir. 2006. Bankarstvo, Subotica, Proleter a.d. Bečej

Zelenović, Vera. 2015. Marketing u bankarstvu. Subotica, Proleter a.d. Bečej

Addiko Bank AD Podgorica, 2018. https://www.addiko.me/o-nama/drustvenaodgovornost/sponzorstva-i-donacije/, (accessed March 17, 2018).

Central bank of Montenegro, 2018. http://www.cbcg.me/index.php?mn1=kontrola_banaka\& mn 2=bankarski_sistem\&mn3=licencirane_banke, (accessed March 17, 2018).

Crnogorska komercijalna banka AD Podgorica member of OTP Group, 2018. http://www.ckb.me/marketing-i-pr/marketing-i-pr.69.html, (accessed March 17, 2018).

ERSTE Bank AD Podgorica, 2018. https://www.erstebank.me/sr_ME/footer-stanovnistvo/obanci/Sponzorstva-i-donacije, (accessed March 17, 2018).ž

Hipotekarna banka AD Podgorica, 2018. http://hipotekarnabanka.com/o-banci/vijesti, (accessed March 17, 2018).

NLB Banka AD Podgorica, 2018. https://www.nlb.me/me/nlb-banka/opste/drustvenaodgovornost, (accessed March 17, 2018).

Prva banka Crne Gore AD Podgorica osnovana 1901. godine, 2018. http://www.prvabankacg.com/o-nama/drustvena-odgovornost/, (accessed March 17, 2018).

Societe Generale banka Montenegro AD, 2018. http://www.societegenerale.me/mne/bankau-javnosti/banka-kao-drustveno-odgovorna-kompanija, (accessed March 17, 2018).

Article history: $\quad$ Received: April 2,2018

Accepted: June 6, 2018 